ICAMS 2016 $-6^{\text {th }}$ International Conference on Advanced Materials and Systems

\title{
BEHAVIOR IN FINISHING OF PCM FIBERS IN BLENDS WITH NATURAL, MAN-MADE OR SYNTHETIC FIBERS
}

\author{
ALINA POPESCU, LAURA CHIRILĂ, DOINA TOMA \\ The National Research and Development Institute for Textiles and Leather (INCDTP), 16 \\ Lucretiu Patrascanu Street, 030508 Bucharest, Romania, email: alina.popescu@certex.ro, \\ laura.chirila@certex.ro,doina.toma@certex.ro
}

\begin{abstract}
Phase Change Material (PCM) is a substance with a high heat of fusion which melts and solidifies at a certain temperature, being capable of storing and releasing large amounts of thermal energy. This behaviour of PCM is the basis for its temperature regulating effect, as a component of textile functionalized fibres and helps the body to stay within the comfortable temperature range. For the finishing of textiles containing PCM fibers, a great importance should be given to each technologic operation, so that the PCMs from the fiber's structure would not be eliminated by preliminary treatments, dyeing or by the final finishing applied procedures. In this study, laboratory pre-treatment and dyeing experiments were made, on knitted fabrics with content of PCM fibers in blends with natural, man-made or synthetic fibers, to enable the overall finishing processes influence on the main physical-mechanical characteristics, dyeability and color fastness properties. Various methods of preliminary treatment and dyeing were applied, specific to each fiber composition of yarns, by using the optimum results obtained in previous performed studies. The behavior during finishing of knitted fabrics varies, depending on the fiber components blended with PCM fibers, without affecting the physical-mechanical characteristics of knitted fabrics. As regards the dyeing process, all samples are uniformly dyed, with color differences depending on the applied finishing process. Dyeing fastness is very good in the case of blends with man-made cellulosic fibers and good in the case of blends with cotton or with synthetic fibers.
\end{abstract}

Keywords: PCM fibers in fiber blends, physical-mechanical characteristics, dyeing behavior

\section{INTRODUCTION}

The modern lifestyle creates today the situation in which the actual aim of textile materials is changing from traditional simple protection to the necessary functionality and added-value (e.g. comfort). Textile material is still considered as the interface between the wearer and the environment, but it needs more active role of adapting to the drastic changes of the physiological needs, in the accordance with the changes in the environment (Jocic, 2010). Development of functional fibers is based on the process of incorporating active chemicals into the fiber in its manufacturing stage, and this technology is rather increasing today, mainly being supported by fiber manufacturers. Integration of PCMs in clothes is a straightforward method to obtain thermo-regulating properties. When body temperatures increase, the PCM melts and absorbs heat from the body. Then, when the temperature drops, the PCM solidifies and the stored heat is released again and thus has the ability to stabilize body temperature. This behavior of PCM is the basis for its temperature regulating effect as a component in textile fibers (Mondal, 2008). In previous studies performed (Popescu et al., 2011), the influence of chemical auxiliaries used in the preliminary process, as well as of the applied technological parameters, on the heat of fusion of textile materials made of cellulosic man-made fibres containing PCM, were determined. In this paper, the influence of finishing operation on knitted fabric with Cell Solution ${ }^{\mathrm{TM}}$ Clima fibers content was studied. This functionalized man-made cellulosic fiber is the newest fiber with thermoregulating features of Smartpolymer GmbH (Germany) and TITK group, developed by a new concept for incorporating PCMs in wet spun cellulose fibers based on direct addition of free PCM to a cellulose solution (***Cell Solution). 
Behavior in Finishing of PCM Fibers in Blends with Natural, Man-made or Synthetic Fibers

\section{EXPERIMENTAL PART}

\section{Materials}

The knitted fabrics used in this study are made of different construction of yarns, as mentioned in Table 1.

Table 1. Knitted fabrics yarns composition

\begin{tabular}{cccl}
\hline Fabric code & Yarn count $(\mathbf{N m})$ & Yarn construction $(\%)$ & \multicolumn{1}{c}{ Yarn mixture } \\
\hline $\mathrm{A}$ & $50 / 1$ & $50 / 50$ & Tencel/ PCM fibers \\
$\mathrm{B}$ & $50 / 1$ & $70 / 30$ & Tencel/ PCM fibers \\
$\mathrm{C}$ & $60 / 1$ & $50 / 20 / 30$ & Cotton/ PA/ PCM fibers \\
$\mathrm{D}$ & $65 / 1$ & $70 / 30$ & PES/ PCM fibers \\
\hline
\end{tabular}

\section{Finishing Procedures}

Pre-treatment and dyeing procedures were applied on piece laboratory dyeing apparatus "Redkrome" (Ugolini-Italy), at a bath ratio of 1:20, according to Table 2.

Table 2. Finishing procedures applied on knitted fabrics with content of PCM fibers

\begin{tabular}{|c|c|}
\hline Code & Finishing operations \\
\hline \multicolumn{2}{|r|}{ Finishing procedures applied on $50 \%$ Tencel/ $50 \%$ PCM fibers knitted fabrics } \\
\hline \multicolumn{2}{|c|}{$\mathrm{AV}_{1} \quad$ scouring $\left(40^{\circ}, 30 \mathrm{~min}\right) \rightarrow$ reactive dyeing } \\
\hline \multicolumn{2}{|r|}{$\mathrm{AV}_{2}$ scouring $\left(85^{\circ}, 30\right.$ min $) \rightarrow$ reactive dyeing $\rightarrow$ bio-polishing (acid cellulase) } \\
\hline $\mathrm{AV}_{3}$ & scouring $\left(40^{\circ}, 30 \mathrm{~min}\right) \rightarrow$ causticizing $\rightarrow$ bio-polishing (acid cellulase) $\rightarrow$ reactive dyeing \\
\hline \multicolumn{2}{|r|}{ Finishing procedures applied on $70 \%$ Tencel/ $30 \%$ PCM fibers knitted fabrics } \\
\hline \multicolumn{2}{|c|}{$\mathrm{BV}_{1} \quad$ scouring $\left(40^{\circ}, 30 \mathrm{~min}\right) \rightarrow$ reactive dyeing } \\
\hline \multicolumn{2}{|r|}{$\mathrm{BV}_{2}$ scouring $\left(85^{\circ}, 30 \mathrm{~min}\right) \rightarrow$ reactive dyeing $\rightarrow$ bio-polishing (acid cellulase) } \\
\hline \multicolumn{2}{|r|}{$\mathrm{BV}_{3}$ scouring $\left(40^{\circ}, 30 \mathrm{~min}\right) \rightarrow$ causticizing $\rightarrow$ bio-polishing (acid cellulase) $\rightarrow$ reactive dyeing } \\
\hline \multicolumn{2}{|r|}{ Finishing procedures applied on $50 \%$ cotton/ $20 \%$ PA/ $30 \%$ PCM fibers knitted fabrics } \\
\hline \multicolumn{2}{|l|}{$\mathrm{CV}_{1}$} \\
\hline \multicolumn{2}{|l|}{$\mathrm{CV}_{2}$} \\
\hline \multicolumn{2}{|l|}{$\mathrm{CV}_{3}$} \\
\hline \multicolumn{2}{|r|}{ 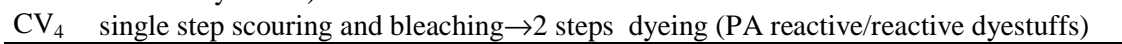 } \\
\hline \multicolumn{2}{|r|}{ Finishing procedures applied on $70 \%$ PES/ $30 \%$ PCM fibers knitted fabrics } \\
\hline \multirow{4}{*}{$\begin{array}{l}\mathrm{DV}_{1} \\
\mathrm{DV}_{2} \\
\mathrm{DV}_{3} \\
\mathrm{DV}_{4}\end{array}$} & scouring $\left(60^{\circ} \mathrm{C}\right) \rightarrow$ drying $\rightarrow$ dry heat-setting $\rightarrow$ dyeing in 2 steps (disperse and reactive) \\
\hline & scouring $\rightarrow$ drying $\rightarrow$ dry heat-setting $\rightarrow$ causticizing $\rightarrow$ bio-polishing $\rightarrow 2$ steps dyeing \\
\hline & scouring $\rightarrow$ drying $\rightarrow$ dry heat-setting $\rightarrow$ causticizing $\rightarrow 2$ steps dyeing $\rightarrow$ bio-polishing $V_{1}$ \\
\hline & scouring $\rightarrow$ drying $\rightarrow$ dry heat-setting $\rightarrow$ causticizing $\rightarrow 2$ steps dyeing $\rightarrow$ bio-polishing $V_{2}$ \\
\hline
\end{tabular}

\section{Physical-Mechanical and Color Measurements}

Physical-mechanical characteristics and color assessment have been made on raw knit fabrics and on final product, as follows:

- physical-mechanical characteristics: mass (SR EN 12127-2003), density (SR 59031993), thickness (SR EN ISO 5084/2001), maximum force - GRAB method (SR EN ISO 13934/2-2002), elongation at maximum force (SR EN ISO 13934/2-2002), abrasion resistance - NU MARTINDALE method (SR EN ISO 12947-2/2002); 
ICAMS 2016 $-6^{\text {th }}$ International Conference on Advanced Materials and Systems

- dyeing performance: color differences (SR EN ISO J01:2003), washing fastness (SR EN ISO 105-C 06:1999), acid perspiration fastness (SR EN ISO 105-E 04:2009), alkaline perspiration fastness (SR EN ISO 105-E 04:2009), rubbing fastness (SR EN ISO 105-X12:2003).

\section{RESULTS AND DISCUSSIONS}

\section{Finishing Operations Influence on Physical-Mechanical Characteristics of Knits}

Table 3. Physical-mechanical characteristics of 50\% Tencel/ 50\% PCM fibers

\begin{tabular}{|c|c|c|c|c|c|c|c|}
\hline \multirow[b]{2}{*}{ Code } & \multirow{2}{*}{$\begin{array}{l}\text { Mass, } \\
\mathrm{g} / \mathrm{m}^{2}\end{array}$} & \multicolumn{2}{|c|}{ Density/10 cm } & \multirow[b]{2}{*}{$\begin{array}{c}\text { Thickness } \\
\text { mm }\end{array}$} & \multirow{2}{*}{$\begin{array}{c}\text { Maximum } \\
\text { force, } \mathrm{N} \\
\text { horizontal }\end{array}$} & \multirow[b]{2}{*}{$\begin{array}{l}\text { Elongation, } \\
\% \text { horizontal }\end{array}$} & \multirow{2}{*}{$\begin{array}{l}\text { Abrasion } \\
\text { resistance, } \\
\text { cycles no. }\end{array}$} \\
\hline & & $\begin{array}{l}\text { course no./ } \\
\text { horizontal }\end{array}$ & $\begin{array}{c}\text { row no./ } \\
\text { vertical }\end{array}$ & & & & \\
\hline Raw & 225 & 110 & 130 & 0.93 & 193.0 & 168.0 & 18810 \\
\hline $\mathrm{AV}_{1}$ & 213 & 109 & 112 & 0.85 & 198.8 & 164.0 & 14243 \\
\hline $\mathrm{AV}_{2}$ & 202 & 106 & 107 & 0.83 & 209.0 & 171.0 & 14652 \\
\hline $\mathrm{AV}_{3}$ & 220 & 104 & 115 & 0.85 & 176.6 & 156.0 & 15079 \\
\hline
\end{tabular}

As regards the influence of the applied finishing processes on the physicalmechanical characteristics of the knitted fabric made of 50\% Tencel/ 50\% PCM fibers the following can be concluded (Table 3):

- the finishing processes induce the decrease of mass, density and thickness characteristics, within normal limits, as compared to raw knitted fabric, indicating the knitted fabric relaxation during finishing: mass decreases by $2-10 \%$, density decreases horizontally by $1-6$ course $/ 10 \mathrm{~cm}$ and vertically by $15-23$ rows $/ 10 \mathrm{~cm}$ and the thickness decreases to less than $0.1 \mathrm{~mm}$;

- maximum force and elongation at maximum force are not negatively influenced by the finishing process, except $\mathrm{AV}_{3}$ sample (which was subjected to causticizing), to which there is a decrease of approx. $8.5 \%$ of maximum force and by $7 \%$ of elongation at maximum force, but these decreases are not significant;

- abrasion resistance decreases as compared to raw knitted fabric by a percentage between $19 \%$ and $24 \%$, this behavior being correlate with the decrease of density in horizontal and vertical direction.

Table 4. Physical-mechanical characteristics of 70\% Tencel/ 30\% PCM fibers

\begin{tabular}{lccccccc}
\hline Code & $\begin{array}{c}\text { Mass } \\
\mathrm{g} / \mathrm{m}^{2}\end{array}$ & $\begin{array}{c}\text { Density/10 cm } \\
\text { course no./ } \\
\text { horizontal }\end{array}$ & $\begin{array}{c}\text { Thickness no./ } \\
\text { vertical }\end{array}$ & $\begin{array}{c}\text { Maximum } \\
\text { force N, } \\
\text { horizontal }\end{array}$ & $\begin{array}{c}\text { Elongation, } \\
\% \text { horizontal }\end{array}$ & $\begin{array}{c}\text { Abrasion } \\
\text { resistance, } \\
\text { cycles no. }\end{array}$ \\
\hline Raw & 208 & 114 & 107 & 1.01 & 158.4 & 207.0 & 21441 \\
$\mathrm{BV}_{1}$ & 199 & 103 & 103 & 0.83 & 188.6 & 194.0 & 18861 \\
$\mathrm{BV}_{2}$ & 208 & 105 & 112 & 0.83 & 214.0 & 161.0 & 16601 \\
$\mathrm{BV}_{3}$ & 199 & 105 & 112 & 0.86 & 211.0 & 159.0 & 18130 \\
\hline
\end{tabular}

The analysis of physical-mechanical characteristics of knitted fabric made of $70 \%$ Tencel/ 30\% PCM fibers (Table 4) indicates the following:

- variation in mass, density and thickness of finished knitted fabric as compared to raw knitted fabric is insignificant; there is a tendency of knitted fabric relaxation in 
horizontal direction for all the finishing variants and contraction in the vertical direction for $\mathrm{BV}_{2}$ sample (scoured at $80^{\circ} \mathrm{C}$ ) and $\mathrm{BV}_{3}$ sample (causticized at $70^{\circ} \mathrm{C}$ );

- maximum force recorded higher values as compared to raw knitted fabric, but the elongation at maximum force decreased by approx. $22 \%$ in $\mathrm{BV}_{2}$ sample and by $23 \%$ in $\mathrm{BV}_{3}$ sample;

- abrasion resistance decreases as compared to raw knitted fabric between $12 \%$ and $23 \%$, this behavior being correlate with the density decrease in horizontal and vertical direction.

Table 5. Physical-mechanical characteristics of 50\% cotton/ 20\% PA/ 30\% PCM fibers

\begin{tabular}{cccccccc}
\hline Code & $\begin{array}{c}\text { Mass } \\
\mathrm{g} / \mathrm{m}^{2}\end{array}$ & $\begin{array}{c}\text { Density/10 cm } \\
\text { course no./ } \\
\text { horizontal }\end{array}$ & $\begin{array}{c}\text { row no./ } \\
\text { vertical }\end{array}$ & $\begin{array}{c}\text { Thickness } \\
\mathrm{mm}\end{array}$ & $\begin{array}{c}\text { Maximum } \\
\text { force, } \mathrm{N} \\
\text { horizontal }\end{array}$ & $\begin{array}{c}\text { Elongation, } \\
\% \\
\text { horizontal }\end{array}$ & $\begin{array}{c}\text { Abrasion } \\
\text { resistance, } \\
\text { cycles no. }\end{array}$ \\
\hline Raw & 174 & 110 & 109 & 0.92 & 128.4 & 181.0 & 28240 \\
$\mathrm{CV}_{1}$ & 197 & 115 & 139 & 0.88 & 215.0 & 167.0 & 60135 \\
$\mathrm{CV}_{2}$ & 222 & 113 & 144 & 0.95 & 242.0 & 177.0 & 55141 \\
$\mathrm{CV}_{3}$ & 180 & 115 & 116 & 0.87 & 219.0 & 189.0 & 56374 \\
$\mathrm{CV}_{4}$ & 200 & 115 & 139 & 0.87 & 210.0 & 145.0 & 52557 \\
\hline
\end{tabular}

In terms of physical and mechanical properties of finished fabrics made of $50 \%$ cotton/ 20\% PA/ 30\% PCM fibers (Table 5), the following can be noticed:

- after finishing there is observed the shrinkage of knitted fabrics, leading to increased values of the mass $\left(\mathrm{g} / \mathrm{m}^{2}\right)$ and density/10 $\mathrm{cm}$, characteristics compared with untreated knit; at the same time, the increasing of maximum force takes place; this behavior is correlated with increased density on the horizontal and vertical direction;

- also, the abrasion resistance is almost doubled as compared to raw knit, this behavior being correlated with increased density on the horizontal and vertical direction.

Table 6. Physical-mechanical characteristics of 70\% PES/ 30\% PCM fibers

\begin{tabular}{lccccccc}
\hline Code & $\begin{array}{c}\text { Mass } \\
\mathrm{g} / \mathrm{m}^{2}\end{array}$ & $\begin{array}{c}\text { Density/10 cm } \\
\text { course no./ } \\
\text { horizontal }\end{array}$ & $\begin{array}{c}\text { row no./ } \\
\text { vertical }\end{array}$ & $\begin{array}{c}\text { Thickness } \\
\mathrm{mm}\end{array}$ & $\begin{array}{c}\text { Maximum } \\
\text { force, } \mathrm{N} \\
\text { horizontal }\end{array}$ & $\begin{array}{c}\text { Elongation, } \\
\% \\
\text { horizontal }\end{array}$ & $\begin{array}{c}\text { Abrasion } \\
\text { resistance, } \\
\text { cycles no. }\end{array}$ \\
\hline Raw & 111 & 111 & 107 & 0.88 & 115.0 & 143.0 & 22689 \\
$\mathrm{DV}_{1}$ & 150 & 129 & 129 & 0.98 & 120.0 & 105.6 & 36058 \\
$\mathrm{DV}_{2}$ & 167 & 140 & 139 & 1.05 & 110.6 & 91.2 & 38299 \\
$\mathrm{DV}_{3}$ & 173 & 146 & 149 & 0.97 & 127.7 & 119.0 & 39303 \\
$\mathrm{DV}_{4}$ & 149 & 124 & 123 & 0.95 & 118.6 & 105.2 & 29780 \\
\hline
\end{tabular}

The finishing process influences the physical-mechanical characteristics of knitted fabric made of fiber blends 70\% PES/ 30\% PCM fibers, as follows (Table 6):

- increased values of the mass, density and thickness, for all types of finishing, as compared with raw knitted fabric, due to the contraction of knitted fabric in wet environment;

- at the same time the increasing of maximum force and abrasion resistance take place;

- however, elongation at maximum force decreases for all types of finishing applied, with values ranging between $16.8 \%$ and $36.2 \%$. 
ICAMS $2016-6^{\text {th }}$ International Conference on Advanced Materials and Systems

\section{Dyeing Process Performance}

Table 7. Dyeing process performance - Colour differences

\begin{tabular}{lccccccccc}
\hline Code & $\mathrm{X}$ & $\mathrm{Y}$ & $\mathrm{Z}$ & & \multicolumn{5}{c}{ Colour difference } \\
& & & & $\mathrm{DL}^{*}$ & $\mathrm{DC}^{*}$ & $\mathrm{DH}^{*}$ & $\mathrm{DE}$ & Mark & Observation \\
\hline $\mathrm{AV}_{1}$ & 54.23 & 58.91 & 11.55 & & & \multicolumn{4}{c}{ REFERENCE } \\
$\mathrm{AV}_{2}$ & 55.44 & 60.42 & 11.41 & 0.82 & 1.85 & 0.35 & 2.05 & $4-5$ & lighter, saturated, greener \\
$\mathrm{AV}_{3}$ & 55.48 & 60.68 & 14.56 & 0.96 & -5.88 & 1.36 & 6.11 & $3-4$ & lighter, unsaturated, greener \\
\hline $\mathrm{BV}_{1}$ & 55.34 & 60.10 & 11.10 & & & \multicolumn{4}{c}{ REFERENCE } \\
$\mathrm{BV}_{2}$ & 55.73 & 60.88 & 12.76 & 0.42 & -3.66 & 1.08 & 3.84 & 4 & lighter, unsaturated, greener \\
$\mathrm{BV}_{3}$ & 56.01 & 60.96 & 12.20 & 0.47 & -2.17 & 0.47 & 2.27 & $4-5$ & lighter, unsaturated, greener \\
\hline $\mathrm{DV}_{1}$ & 21.55 & 12.01 & 11.27 & & & \multicolumn{4}{c}{ REFERENCE } \\
$\mathrm{DV}_{2}$ & 20.19 & 11.26 & 10.95 & -1.22 & -1.38 & -1.11 & 2.15 & 4 & darker, unsaturated, bluer \\
$\mathrm{DV}_{3}$ & 18.35 & 10.15 & 9.61 & -3.12 & -2.51 & -0.32 & 4.02 & 3 & darker, unsaturated, bluer \\
$\mathrm{DV}_{4}$ & 20.04 & 11.23 & 11.05 & -1.26 & -1.94 & -1.44 & 2.73 & 4 & darker, unsaturated, bluer \\
\hline
\end{tabular}

Evenness of dyeing was obtained for all finishing variants. In the case of $50 \%$ Tencel $/ 50 \%$ PCM fibers and 70\% Tencel/ 30\% PCM fibers, color differences between samples were of $1 / 2-1 \frac{1}{2}$ tone, which is normal when different types of pretreatment are applied. In finishing processes which include bio-polishing operations $\left(\mathrm{AV}_{2}, \mathrm{BV}_{2}\right)$ and causticizing-bio-polishing $\left(\mathrm{AV}_{3}, \mathrm{BV}_{3}\right)$, lighter colors are obtained, as compared to the reference sample $\left(\mathrm{AV}_{1}, \mathrm{BV}_{1}\right)$. Knit sample made of $70 \%$ PES/ 30\% PCM fibers which were subjected to causticizing $\left(\mathrm{DV}_{2}, \mathrm{DV}_{3}, \mathrm{DV}_{4}\right)$ are more intensely dyed than the reference sample (non-causticized $\mathrm{DV}_{1}$ ), the color difference ranging between 1-2 tone.

Table 8. Dyeing process performance - Color fastness

\begin{tabular}{|c|c|c|c|c|c|c|c|c|c|c|c|c|c|c|}
\hline \multirow[t]{2}{*}{ Code } & \multicolumn{4}{|c|}{ Washing } & \multicolumn{4}{|c|}{ Acid perspiration } & \multicolumn{4}{|c|}{ Alkaline perspiration } & \multicolumn{2}{|c|}{ Rubbing } \\
\hline & $\begin{array}{l}\text { Color } \\
\text { change }\end{array}$ & $\begin{array}{l}\mathrm{Co} \\
\mathrm{CO}\end{array}$ & $\begin{array}{l}\text { lor st } \\
\text { PA }\end{array}$ & $\begin{array}{r}\text { aining } \\
\text { PES }\end{array}$ & $\begin{array}{l}\text { Color } \\
\text { change }\end{array}$ & $\begin{array}{l}\text { Colo } \\
\mathrm{CO}\end{array}$ & $\begin{array}{l}\text { or sta } \\
\text { PA }\end{array}$ & $\begin{array}{c}\text { ining } \\
\text { PES }\end{array}$ & $\begin{array}{l}\text { Color } \\
\text { change }\end{array}$ & $\begin{array}{l}\mathrm{Col} \\
\mathrm{CO}\end{array}$ & $\begin{array}{c}\text { or st } \\
\text { PA }\end{array}$ & $\begin{array}{r}\text { aining } \\
\text { PES }\end{array}$ & Dry & Wet \\
\hline$\overline{\mathrm{AV}_{1}}$ & $4 / 5$ & 5 & 5 & 5 & 5 & $4 / 5$ & 5 & 5 & 5 & $4 / 5$ & 5 & 5 & 5 & 45 \\
\hline $\mathrm{AV}_{2}$ & 5 & 5 & 5 & 5 & 5 & $4-5$ & $4 / 5$ & 5 & 5 & $4 / 5$ & 5 & 5 & 5 & 4 \\
\hline $\mathrm{AV}_{3}$ & 5 & 5 & 5 & 5 & 5 & 5 & 5 & 5 & 5 & 5 & 5 & 5 & 5 & $4 / 5$ \\
\hline $\mathrm{BV}_{1}$ & $4-5$ & 4 & 5 & 5 & 5 & $4 / 5$ & $4 / 5$ & 5 & $4 / 5$ & 4 & $4 / 5$ & $4 / 5$ & 5 & 5 \\
\hline $\mathrm{BV}_{2}$ & 5 & 5 & 5 & 5 & 5 & 5 & 5 & 5 & 5 & 5 & 5 & 5 & 5 & 5 \\
\hline $\mathrm{BV}_{3}$ & 5 & $4-5$ & 5 & 5 & 5 & $4 / 5$ & 5 & 5 & 5 & $4 / 5$ & 5 & 5 & 5 & 5 \\
\hline $\mathrm{CV}_{1}$ & $4 / 5$ & $4 / 5$ & $4 / 5$ & $4 / 5$ & 4 & 4 & $4 / 5$ & $4 / 5$ & 4 & $3 / 4$ & $4 / 5$ & $4 / 5$ & $4-5$ & $3 / 4$ \\
\hline $\mathrm{CV}_{2}$ & $4 / 5$ & 4 & 4 & $4 / 5$ & $4 / 5$ & $4 / 5$ & 4 & $4 / 5$ & $4 / 5$ & 4 & 4 & $4 / 5$ & 5 & $4 / 5$ \\
\hline $\mathrm{CV}_{3}$ & 5 & 5 & 5 & 5 & $4 / 5$ & 5 & 5 & 5 & $4 / 5$ & $4 / 5$ & $4 / 5$ & 5 & 5 & $4 / 5$ \\
\hline $\mathrm{CV}_{4}$ & $4 / 5$ & 4 & $4-5$ & $4 / 5$ & 4 & 4 & $4 / 5$ & 4 & 4 & $4 / 5$ & $4 / 5$ & $4 / 5$ & $4-5$ & 3 \\
\hline $\mathrm{DV}_{1}$ & $4 / 5$ & 4 & 3 & $3 / 4$ & $4 / 5$ & $4 / 5$ & $4 / 5$ & $4 / 5$ & $4 / 5$ & $4 / 5$ & $4 / 5$ & $4 / 5$ & 5 & $4 / 5$ \\
\hline $\mathrm{DV}_{2}$ & $4 / 5$ & $4 / 5$ & $3 / 4$ & 4 & $4 / 5$ & $4 / 5$ & $4 / 5$ & $4 / 5$ & $4 / 5$ & $4 / 5$ & $4 / 5$ & $4 / 5$ & 5 & $4 / 5$ \\
\hline $\mathrm{DV}_{3}$ & $4 / 5$ & 4 & $2 / 3$ & $3 / 4$ & $4 / 5$ & $4 / 5$ & $4 / 5$ & $4 / 5$ & $4 / 5$ & $4 / 5$ & $4 / 5$ & $4 / 5$ & 5 & $4 / 5$ \\
\hline $\mathrm{DV}_{4}$ & 4 & 4 & 2 & $3 / 4$ & $4 / 5$ & 4 & 4 & $4 / 5$ & $4 / 5$ & 4 & 4 & 4 & 4 & 4 \\
\hline
\end{tabular}

In terms of color fastness properties (Table 8) it has been noticed that the dyeing fastness to washing, acid/alkaline perspiration, wet/dry rubbing is very good in blends of PCM fibers with Tencel fibers dyed with a bi-functional reactive dyestuff, the marks obtained in this case for change of shade and staining of the multi-fiber standard ranging between 4-5/5 (predominantly 5). An improved fastness to washing and alkaline perspiration is noted, in case of samples which include bio-polish operation, 
marks obtained in the change of shade being higher by $1 / 2$ tone. The dyeing fastness is generally good in blends of PCM fibres with cotton/PA or with PES, most of marks being 4-5/5 (predominantly 4-5). Lower fastness to alkaline perspiration and wet rubbing (marks 3/3-4) are obtained in the case of 2 steps dyeing with reactive/selected reactive dyes (for wool/PA type fibers) of cotton/PA/PCM fiber blends $\left(\mathrm{CV}_{1}, \mathrm{CV}_{4}\right)$. Also, lower washing fastness is obtained in the case of PES/PCM fiber blends subjected to bio-polishing subsequent to the dyeing operation $\left(\mathrm{DV}_{3}, \mathrm{DV}_{4}\right)$ where the staining of PA and PES standard fibers is high (marks 2/2-3/3-4). From this reason it is recommended to perform the bio-scouring operation before the dyeing operation.

\section{CONCLUSIONS}

All finishing processes applied on knitted fabrics made of PCM fibers in blends with natural, man-made or synthetic fibers are appropriate and do not negatively affect the physical-mechanical characteristics of knitted fabrics. The behavior during finishing of knitted fabrics varies, depending on the fiber components blended with PCM fibers. In the case of blends with Tencel fibers, the knitted fabric relaxes during finishing, inducing decrease under normal limits of mass, density and thickness characteristics, without negatively influencing maximum force and elongation at maximum force. In the case of blends with cotton/PA fibers or with PES fibers, the knitted fabric shrinks, leading to increased values of mass, density and thickness characteristics. At the same time maximum force and abrasion resistance increase. The decreasing of the elongation at maximum force after finishing of knitted fabric containing 70\% PES is under normal limits. This is caused by the heat-setting operation. As regards the dyeing process, all samples are uniformly dyed with color differences depending on the applied finishing process. Dyeing fastness is very good in blends of PCM fibers with Tencel fibres and good in blends of PCM fibres with cotton/PA or with PES fibers.

\section{Acknowledgement}

This work was supported by a grant of the National Authority for Scientific Research and Innovation (ANCSI), contract no. 26N/14.03.2016, PN 16340304.

\section{REFERENCES}

Jocic, D. (2010), "Functional finishing of textiles with responsive polymeric systems", Surface modification systems for creating stimuli responsiveness of textiles, D. Jocic Ed., University of Twente, Enschede, The Netherlands, pp. 37-59.

Mondal, S. (2008), "Phase change materials for smart textiles - An overview", Applied Thermal Engineering, 28 , pp. 1536-1550.

Popescu, A., Mocioiu, A.M. and Hulea, C. (2011), "Study procedures for finishing textile materials with PCM content", Proceedings of The $4^{\text {th }}$ TexTeh International Conference, Bucharest, pp.67-75.

***http://www.cellsolution.eu/products/cell-solution-climafiber/ 